\title{
Penerapan Metode Inkuiri dalam Meningkatkan Keterampilan Berpikir Kritis dan Keaktifan Belajar Siswa Pada Mata Pelajaran PAI di MTs Al-Amin Pekalongan
}

\author{
Failasuf Fadli \\ IAIN Pekalongan
}

\section{Edcomtech}

\author{
Jurnal Kajian \\ Teknologi Pendidikan
}

Volume 4, No 1, April 2019

19-26

Submitted 01-18-2019

Accepted 04-07-2019

\section{Corresponding Author}

Failasuf Fadli

failasuffadli@gmail.com

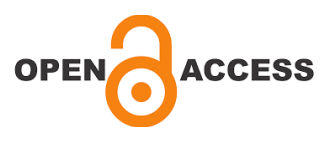

\begin{abstract}
Abstrak
Kurangnya pemahaman siswa pada materi Pendidikan Agama Islam (PAI) di sekolah merupakan salah satu masalah serius yang dihadapi guru. Selain itu, siswa juga tidak antusias dalam merespon materi yang disampaikan gurunya.Perilaku yang seperti itu disebabkan karena materi PAI dianggap tidak semenarik materi lain, selain itu model pembelajaran yang terlalu sering digunakan menjadikan siswa kurang aktif serta belum dapat mengembangkan ketrampilannya dalam berpikir kritis. Hal ini dapat dilihat dari perilaku siswa di kelas cenderung hanya melihat dan mendengar materi pelajaran yang diberikan gurunya. Sedangkan Pembelajaran PAI merupakan materi yang penting bagi kehidupan sehari-hari siswa, karena tidak hanya terkait duniawi saja, melainkan terkait dengan kehidupan akhirat kelak.. Untuk mencapai hasil pembelajaran yang maksimal, maka guru diharapkan dapat menerapkan suatu metode pembelajaran yang dapat mengembangkan pola pikir siswa. Metode pembelajaran yang dimaksud salah satunya adalah metode pembelajaran inkuiri. Implentasi metode inkuiri pada mata pelajaran PAI dapat meningkatkan daya berpikir kritis dan keaktifan siswa dalam proses belajar mengajar. Penelitian ini menggunakan metode penelitian kualitatif dengan sumber primer guru yang mengampu mata pelajaran PAI (Fiqih, al-Qur'an Hadist, Aqidah Akhlak, Sejarah kebudayaan Islam) dan peserta didik MTs Al-Amin Pekalongan. Proses Penelitian ini mengikuti prosedur reduksi data, penyajian data dan membuat kesimpulan. Adapun hasil dari penilitian ini mengemukakakn bahwa pembelajaran inkuiri adalah pembelajaran dengan berusaha semaksimal mungkin melibatkan potensi fisik dan intelegensi siswa untuk berpikir mencari dan menyelidiki suatu masalah yang dikemukakan guru secara sistematis dan logis, akan berdampak pada siswa sehingga siswa dapat memberikan jawaban yang didasarkan pada pengetahuan, sikap dan keterampilan. Dengan penggunaan seluruh pengetahuan yang dimiliki siswa dapat menggerakkan jiwa serta menimbulkan kemampuan dalam berpikir kritis serta aktif.
\end{abstract}

Kata Kunci: metode inkuiri, berpikir, kritis, aktif

\begin{abstract}
The lack of understanding of students in Islamic Education (PAI) material in schools is one of the serious problems faced by teachers. In addition, students are also not enthusiastic in responding to the material delivered by the teacher. Such behavior is caused because PAI material is considered not as interesting as other material, besides the learning model that is too often used makes students less active and unable to develop critical thinking skills. This can be seen from the behavior of students in the class tend to only see and hear the subject matter given by the teacher. Whereas PAI Learning is an important material for the daily lives of students, because it is not only related to the world, but also related to the afterlife. To achieve maximum learning outcomes, the teacher is expected to be able to apply a learning method that can develop students' mindsets. . One of the learning methods in question is inquiry learning method. The implication of the inquiry method on PAl subjects can improve critical thinking power and student activity in the teaching and learning process. This research uses qualitative research methods with primary sources of teachers who teach PAl subjects (Fiqh, al-Qur'an Hadist, Aqidah Akhlak, History of Islamic culture) and MTs AlAmin Pekalongan students. This research process follows the procedure of data reduction, data presentation and conclusions. The results of this study suggest that inquiry learning is learning as much as possible involving the physical potential and intelligence of students to think looking for and investigating a problem that the teacher put forward systematically and logically, will have an impact on students so students can provide answers based on knowledge, attitude and skills. With the use of all the knowledge possessed by students can move the soul and lead to the ability to think critically and actively.
\end{abstract}

Keywords: inquiry method, thinking, critical, active 


\section{LATAR BELAKANG}

Pendidikan merupakan kegiatan sadar yang direncanakan oleh manusia baik secara individu mandiri maupun sebagai makhluk sosial bermasyarakat dalam hal meningkatkan kemampuan berpikir agarmenghasilkan suatu manfaat, baik bagi diri sendiri maupun kepada orang lain (Triswanti, 2017:175). Menurut wina sanjaya, pendidikan adalah usaha sadar yang direncanakan untuk mewujudkan suasana belajar yang menyenangkan dan proses pembelajaran yang aktif, sehingga dapat mengembangkan kemampuan dan potensi diri yang dimilki siswa tersebut. Proses ini melibatkan dan mengikut sertakan berbagai jenis komponen kemampuan potensi diri untuk mencapai tujuan yang diinginkan. Komponen potensi diri sangat berperan penting dalam meningkatkan daya berpikir siswa yang diantaranya adalah tujuan yang ingin dicapai, kondisi siswa, sumber dan hasil belajar (Sanjaya, 2011). Undang-undang nomor 20 tahun 2003 menyatakan dengan jelas tentang tujuan pendidikan nasional. Tujuan Pendidikan nasional secara garis besar dapat dibagi menjadi dua aspek, aspek rohani dan aspek jasmani. Secara rohani, tujuan pendidikan nasional mempunyai peran untuk menghantarkan manusia menjadi manusia yang beriman dan bertakwa kepada Tuhan Yang Maha Esa. Sedangkan aspek jasmani tujuan pendidikan nasional adalah membentuk masyarakat Indonesia menjadi manusia luhur yang mempunyai kepribadian yang unggul, cerdas, kreatif, mandiri dan mempunyai rasa tanggung jawab kemudian dua aspek diatas dibalut dengan rasa nasionalisme yang tinggi.

Tujuan itu dijabarkan dalam kurikulum, wujud penjabaran dalam kurikulum tersebut diturunkan dalam suatu mata pelajaran. Tujuan mata pelajaran selain mengarahkan siswa untuk mengatahui kemampuan akademik suatu materi, namun ada tujuan yang lebih tinggi dari itu, yakni tujuan untuk mengakui keagungan Tuhan sehiingga mampu menjadikan manusia yang mempunyai Iman dan takwa kepada Allah SWT yang menghasilkan manusia adil, jujur, saling menghargai, disiplin, arif bijaksana, berbudi pekerti luhur dan produktif baik individu personal maupun sosial masyarakat.
Pasca era reformasi kemajuan bangsa Indonesia mulai tampak dikalangan masyarakat, yang sebelumnya pendidikan formal tidak begitu dipandang penting kemudian sedikit demi sedikit mulai dibutuhkan sebagian besar masyarakat Indonesia. Sehingga salah satu ukuran kesejahteraan sesorang atau keluarga dapat dilihat dari seberapa tinggi orang tersebut mengenyam pendidikan. Semakin orang yang berpendidikan tinggi berbanding lurus dengan kesejahteraan orang tersebut, hal ini juga dikarenakan pendidikan di Indonesia masih memerlukan beaya yang tidak sedikit. Namun, orang yang berpendidikan belum tentu juga mempunyai kualitas pendidikan yang baik. Hal ini dikarenakan banyak faktor yang menjadikan pendidikan berkualitas. Proses pembelajaran merupakan faktor yang penting dalam menciptakan pendidikan yang berkualitas, yang didalamnya terdapat suatu materi pelajaran yang diampu oleh guru, salah satunya adalah materi Pendidikan Agama Islam. Proses pembelajaran menjadi sangat berperan ketika guru dapat menguasai materi dengan baik, kemudian juga memiliki metode pembelajaran yang efektif, efisien dan menarik

Untuk menghasilkan pendidikan yang berkualitas tentunya memerlukan guru yang memiliki kompetensi guru, hal ini sejalan dengan Undang-undang nomor 14 tahun 2015. Kompetensi pedagogik merupakan salah satu kompetensi yang wajib dimiliki guru PAI. Penguasaan manajemen pembelajaran menjadi suatu keharusan yang harus di miliki guru, dari proses perencanaan yang diwujudkan dalam bentuk rencana pembelajaran, pelaksanaan pembelajaran sampai dengan evaluasi pembelajaran. Sejak perencanaan pembelajaran, kreatifitas guru sudah dapat dilihat seberapa tingkat kualitas pembelajaran yang direncanakan. Metode apa yang akan di rencanakan dalam proses pembelajaran. Bagaimana cara mengeksplore siswa agar dapat menerima materi dengan mudah, Pembelajaran berjalan secara menyenangkan, sehingga dapat siswa dapat merespon baik bertanya maupun menjawab atas diskusi pada saat pembelajaran. Aspek pedagogic juga diwujudkan dalam bentuk 
berbagai macam cara evaluasi digunakan, sehingga siswa melaksanakan tes/evaluasi secara gembira. Aspek kompetensi yang berkutnya yang harus dimiliki guru adalah kompetensi kepribadian. Perilaku luhur merupakan cerminan manusia yang mempunyai peradaban tinggi. Guru selalu menjaga perilakunya baik ketika di sekolah maupun di luar sekolah. Bertindak sesuai norma yang ada, baik norma agama, hukum ataupun adat istiadat,sehingga menghasilkan akhlakul karimah yang dapat dijadikan teladan secara langsung oleh siswanya. Kompetensi yang harus dikuasai selain pedagogik dan kepribadian adalah professional. Guru PAI harus menguasai konsep dan pola pikir suatu materi dengan baik, dapat memanfaatkan teknologi pendidikan untuk mendukung proses pembelajarannya. Kompetensi yang terkahir yang harus dimiliki gur adalah kompetensi sosial. Guru mampu beradaptasi dengan lingkungannya dengan baik. Menjalin komunikasi dengan warga sekolah (kepala sekolah, guru, siswa,dll) maupun berkomunikasi dengan masyarakat pada umumnya. Dapat memilih kalimat/perkataan yang akan diucapkan baik ketika proses pembelajaran maupun diluar pembelajaran (Nurtanto, 2016).

Sekalipun seorang guru sudah mempunyai kompetensi, namun masih saja muncul Permasalahan yang dialami atau ditemui dalam proses belajar mengajar mata pelajaran PAI yaitu rendahnya kemampuan berpikir kritis dan keaktifaan siswa, karena penggunaan metode pembelajaran yang monoton menjadikan siswa jenuh. Serta fokusnya berkurang karena siswa merasa bosan dalam proses belajar mengajar. Berdasarkan permasalahan diatas, maka dapat dikatakan bahwa pemilihan suatu metode pembelajaran yang tidak tepat akan berpengaruh pada minat dan suasana belajar siswa. Karena kenyataannya tidaklah mudah dalam menentukan, memilih, dan menggunakan model pembelajaran dan sering ditemukan di lapangan penggunaan metode yang kurang efektif dan efisien, sehingga dapat membuat suasana kelas tidak kondusif dan berakibat kurangnya kemampuan berpikir kritis dan keaktifan belajar siswa.
Untuk tercapainnya proses belajar tersebut, maka seorang guru harus menentukan metode apa yang sekirannya menjadikan anak berpikir kritis dan aktif belajar. Metode inkuiri merupakan salah satu metode yang menggunakan seluruh kemampuan fisik dan pikiran siswa secara sistematis, logis dan kritis yang berdasarkan pada teori akademik dalam mencari permasalahan yang ada di lingkungannya kemudian merumuskan dan mengemukakan solusi jawaban atas permasalahan yang dihadapinya.

Dari penjabaran diatas dapat direduksi bahwa dalam proses pembelajaran tidak seharusnya bersifat monoton, yang menjadikan siswa bosan atau jenuh dalam pelaksanaannya. Dengan penerapan metode inkuiri maka hal yang harus di perhatikan ialah bagaimana cara meningkatkanan kemampuan berpikir kritis siswa dengan menerapkan metode inkuiri pada mata pelajaran PAI? Bagaimana dan seperti apa bentuk pembelajaran aktif dengan menggunakan model inkuiri dalam mata pelajaran PAI?. Secara teoritik akademik, penelitian ini diharapkan dapat memberikan konstribusi khasanah keilmuan teerhadap penerapan metode yang digunakan untuk meningkatkan berpikir kritis siswa sehingga aktif dalam proses belajar mengajar.

\section{METODE PENELITIAN}

Artikel ini dihasilkan dari penelitian dengan mengunakan pendekatan kualitatif artinya menggunakan data dengan menekankan pada kalimat verbal dalam menggali masalah secara mendalam kemudian data tersebut diolah secara rasional dengan pola berpikir induktif. (Arikunto, 1998:120). Dalam hal ini menggunakan teknis metode berpikir yang berangkat dari pengetahuan atau peristiwaperistiwa konkret, dari pola yang merujuk pada kejadian khusus kemudian ditarik pada pola umum yang bersifat generalisasi. (Sugiono, 2010). Objek lokasi dalam penelitian ini adalah MTs Al-Amin Pekalongan dengan sumber primer guru rumpun Pendidikan Agama Islam berjumlah empat, yakni mata pelajaran alQur'an Hadist, Fiqih, Aqidah Akhlak dan Sejarah kebudayaan Islam. Selain guru juga peserta didik di kelas 
VIII sebanyak 6, yang kedua sumber primer tersebut diwawancarai secara mendalam.

Metode pengumpulan data juga dilakukan melalui observasi di tempat penelitian dalam hal ini di MTs Al-Amin Pekalongan, selain itu mengambil dokumentasi atas data-data yang mendukung dalam penelitian ini. Adapun Teknik analisis data merujuk kepada Miles dan huberman yang meliputi reduksi data dengan merangkum, menilai hal-hal yang pokok, memfokuskan pada hal-hal yang penting, dicari tema dan polanya serta membuang yang tidak perlu. Selanjutnya ada penyajian data dengan menyajikan sekumpulan informasi tersusun yang memberi kemungkinan adanya penarikan kesimpulan dan pengambilan tindakan.

Kemudian yang terakhir adalah verifikasi yaitu suatu kegiatan yang berupa pengambilan intisari dan penyajian data yang merupakan hasil dari analisis yang dilakukan (Sugiono, 2010:334).

\section{HASIL DAN PEMBAHASAN \\ Metode Inkuiri}

Kata inkuiri merupakan suatu kata yang berasal dari bahasa Inggris (Inquiry) yang secara bahasa mempunyai arti "penyelidikan". Kata penyelidikan jika dikaitkan dalam proses pembelajaran, maka akan berkembang menjadi suatu pola kata yang hampir sama, diantaranya, ingin mencari tahu, memeriksa suatu objek, menanyakan sesuatu, meminta keterangan, mencari informasi, dll. Dari pola bahasa tersebut kemudian terus berkembang menjadi suatu metode khusus dalam suatu pembelajaran yang disebut metode pembelajaran inkuiri. Metode ini mempunyai spesifikasi dalam hal menyelidiki suatu permasalahan yang dihadapi oleh siswa dengan menggunakan seluruh kemampuan fisik dan kemampuan pikiran untuk mencari jawaban atau solusi atas permasalahan tersebut secara sistematis, logis dan kritis (Hanafiah, 2009:77).

Metode inkuiri suatu metode yang menjadikan siswa sebagai subyek, ikut serta dalam memecahkan masalah, menyelidikinya secara sistematis, logis, dan kritis sehingga adanya perubahan terhadap pengetahuan serta keterampilan siswa. Dengan metode tersebut menjadikan siswa aktif dalm proses belajar. MTs Al-Amin Pekalongan sebuah lembaga pendidikan dibawah naungan Kementerian Agama yang proses belajar mengajarnya sudah menggunakan berbagai metode pembelajaran, diantaranya menggunakan metode pembelajaran inkuiri di mata pelajaran rumpun PAI. Dalam penggunaan metode inkuiri guru MTs Al-Amin Pekalongan memperhatikan beberapa prinsip diantaranya seperti gambar berikut:

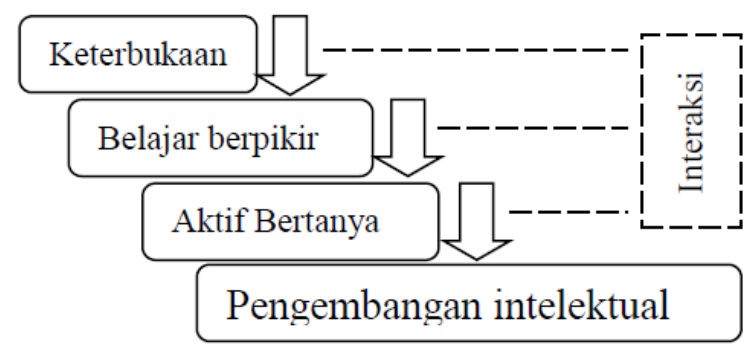

Gambar 1. Bagan Proses Tahapan Prinsip Pembelajaran Metode Inkuiri

Belajar adalah suatu cara untuk menemukan sesuatu hal yang baru. Sehingga cara untuk memperoleh suatu hal yang baru itu diantaranya memberikan ruang dan waktu untuk berpikir bebas yang disertai dengan kemampuan berpikir logis dalam penalaran. Belajar yang berkualitas mempunyai ciri salah satunya adalah apa yang ditemukan dapat dipertanggungjawabkan secara ilmiah kebenarannya. Maka dari itu, salah satu kewajiban guru adalah membimbing siswa untuk berpikir aktif dengan mengembangkan seluruh kemampuan fisik dan menyeimbangkan kemampuan antara otak kanan dan otak kiri dalam proses pembelajaran siswa. Peran guru dalam prinsip bertanya, guru merupakan penanya. Siswa yang harus menjawab. Dari proses bertanya ini maka siswa dapat mengembangkan keterampilan berpikirnya untuk menjawab pertanyaan dari guru. Bertanya disini dalam rangka mengembangkan dan menguji kemampuan siswa.

Kegiatan di atas merupakan kegiatan bersama diantara warga MTs Al-Amin Pekalongan yang meliputi siswa, guru, dan pimpinan sekolah sebagai pengambil kebijakan dalam hal ini diwujudkan dalam 
suatu kurikulum. Dalam Kurikulum 2013 menyebutkan bahwa guru bukan lagi menjadi Teacher Center, namun berlaku seperti fasilitator dalam pembelajaran yang mengarahkan agar siswa bisa mengembangkan pemikirannya melalui interaksi. Proses interaksi dapat dilakukan dimana saja, apalagi dengan perkembangan teknologi komunikasi terkini, siswa dapat berinteraksi selama 24 jam tanpa bertemu dan dimanapun berada, hanya dengan menggunakan smartphone. Sehingga proses interaksi pembelajaran tidak dibatasi oleh ruang dan waktu. Hasil dari interaksi tersebut adalah suatu pengembangan intelektual dengan pola mengembangkan kemampuan berpikir, dimana strategi ini lebih berorientasi terhadap hasil proses belajar siswa di kelas.

Keberhasilan tersebut dilihat dari proses pembelajaran yang dilakukan sejauh mana siwsa dapat mengidentifikasi, memahami, dan mendalami suatu materi, serta menghasilkan sesuatu yang baru dan original dalam suatu aktifitasnya. Untuk itu ide merupakan suatu yang sangat dibutuhkan dan dikembangkan untuk menunjang proses pembelajaran. Prinsip-prinsip diatas juga sejalan dengan fungsi metode inkuiri yang meliputi: Membangun komitmen (commitment bulding). Membangun pembelajaran yang bersifat aktif kreatif yang disertai inovatif kebaruan. Membentuk kepercayaan diri yang tinggi dan mengarahkan agar siswa mempunyai cara pandang dan cara berpikir yang terbuka terhadap hasil yang ditemukan siswa tersebut (Hanafiah, 2009:78).

\section{Langkah-Langkah Pembelajaran}

Pembelajaran inkuiri bukan hanya sekedar mengembangkan kemampuan Intlegensi saja akan tetapi pembelajaran yang melibatkan semua kamampuan yang dimiliki siswa termasuk didalamnya ketrampilan mengolah data dan kemampuan emosional.

Pembelajaran inkuiri berawal dari meruntut akar permasalahan, kemudian mengidentifikasi masalah, mengklasisifkasi msaalah, selanjutnya mengemukakan hipotesis, menyajikan dan menganalisis data dan yang terakhir adalah membuat kesimpulan (Al-Tabany, 2014:78). Adapun proses pembelajaran dengan menggunakan metode inkuiri di MTs Al-Amin sebagai berikut:

Tabel 1. Table Proses Pembelajaran dengan Metode Inkuiri

\begin{tabular}{ll}
\hline No & \multicolumn{1}{c}{ Kegiatan } \\
\hline $\mathbf{1}$ & Eksplorasi kebutuhan siswa \\
\hline $\mathbf{3}$ & $\begin{array}{l}\text { Pemilihan konsep materi } \\
\text { akan dipelajari }\end{array}$ \\
$\mathbf{4}$ & $\begin{array}{l}\text { Menemtukan peran yang akan } \\
\text { dilakukan masing-masing siswa }\end{array}$ \\
$\mathbf{5}$ & $\begin{array}{l}\text { Mengecek pemahaman peserta } \\
\text { didik terhadap masalah yang akan } \\
\text { diselidiki dan ditemukan }\end{array}$ \\
$\mathbf{6}$ & $\begin{array}{l}\text { setting kelas dan fasilitas yang } \\
\text { diperlukan }\end{array}$ \\
\hline $\mathbf{7}$ & $\begin{array}{l}\text { Memberikan kesempatan kepada } \\
\text { peserta didik untuk melakukan } \\
\text { penyelidikan dan penemuan }\end{array}$ \\
\hline $\mathbf{8}$ & $\begin{array}{l}\text { Analisis Mandiri atas data temuan } \\
\text { Merangsang terjadinya dialog } \\
\text { interakti antar siswa }\end{array}$ \\
\hline $\mathbf{1 0}$ & $\begin{array}{l}\text { Memberikan penguatan kepada } \\
\text { peserta didik untuk giat dalam } \\
\text { melakukan penemuan }\end{array}$ \\
\hline $\mathbf{1 1}$ & $\begin{array}{l}\text { Siswa melakukan generalisasi atas } \\
\text { hasil penemuannya berdasarkan } \\
\text { prinsip-prinsip akademik }\end{array}$ \\
\hline
\end{tabular}

Hasil observasi yang dilakukan peneliti pada saat pembelajaran menggunakan metode inkuiri di MTs Al-Amin Pekalongan sebagai berikut:

Guru memberikan fasilitas dengan memberikan dorongan (motivasi) kepada siswa untuk melaksanakan pembelajaran sesuai dengan tahapan yang telah dirumuskan. Dengan menggunakan metode tersebut guru benar-benar menjadi fasilitator dalam pembelajaran. Guru memberikan kebebasan siswa dalam pemilihan mencari infromasi untuk dapat memahami secara mendalam materi shalat lima waktu yang sedang dibahas. Kebebasan siswa untuk memperkuat kreativitas dan imajinasinya 
dalam memperkuat pemahamannya tentang materi pembelajaran shalat lima waktu.

Guru PAI melakukan interaksi dengan siswa yang mengarah pada upaya guru untuk memberikan kesempatan kepada siswa untuk berpikir kritis, memberdayakan rasa ingin tahu, dan hal tersebut dapat melatih siswa untuk memperkuat daya pikirannya. Untuk itu maka guru PAI harus berusaha agar siswa dapat memahami materi pembahasan shalat lima waktu dan sub materi membahas shalat lima waktu, definisi, syarat dan rukun shalat lima waktu serta hal-hal yang menyebabkan batalnya shalat.

Guru memfasilitasi siswa dalam mencapai keberhasilan belajar. Guru menyediakan sumber belajar berupa buku dan referansi lain yang membahas syarat dan rukun dalam shalat, hal-hal yang membatalkan shalat. Guru memberikan kesempatan kepada siswa untuk dapat memecahkan masalah yang dirumuskan siswa yang berkaitan dengan shalat dibawah bimbingan guru. Dalam hal ini guru melatih siswa untuk mampu merumuskan masalah yang muncul dan harus dibahas serta mencari jawaban terhadap permasalahan tersebut dengan menggunakan metode inkuiri.

Dengan metode inkuiri yang pembelajarannya dilakukan dengan berkelompok, serta saling menukar pendapat atau pengetahuan antara siswa yang satu dengan yang lainnya. Menjadikan proses pembelajaran tersebut aktif serta siswa-siswi pun aktif dalam menyampaikan pendapat dari masing-masing kelompok, lalu memecahkan masalah dengan mencari pengetahuan dari referensi lain sehingga sedikit demi sedikit membentuk pola kebiasaan dengan berpikir kritis.

\section{Berpikir Kritis}

Berpikir kritis adalah kemampuan seseorang untuk berpendapat secara yang terorganisasi (Johnson, 2009:183). Selain itu, berpikir kritis adalah suatu pertimbangan yang aktif, terus-menerus, detail dan teliti mengenai sebuah keyakinan atau seuatu pengetahuan yang dilihat dari sudut penyebab yang mendukungnya dan kesimpulan-kesimpulan lanjutan yang menjadi kemungkinannya (dewey dalam fisher, 2008:2).

Beberapa perilaku yang mencerminkan ketrampilan berpikir kritis siswa di MTs AlAmin Pekalongan adalah: Siswa aktif bertanya baik kepada guru maupun siswa lain. Aktif bertanya merupakan modal awal yang dimiliki siswa dalam berinteraksi di kelas maupun di luar kelas, sehingga terciptalah suatu gagasangagasan materi. Siswa Mts Al-Amin dapat memahami suatu gagasan dengan baik dan sistematis. Gagasan yang berasal dari guru mapun siswa lain diserap kemudian dipahami secara seksama. Perilaku ini mencerminkan bahwa tujuan berpikir kritis adalah untuk mencapai penilaian yang yang dibuktikan dengan pencarian dan penghimpunan informasi sebagai suatu strategi yang tersusun secara sistematis dan logis serta memiliki standar yang pada akhirnya menghasilkan penilaian atau cara pandang yang detail dan menyeluruh. (Syafei, 2015:140). Perilaku lain yang mencerminkan berpikir kritis adalah siswa mampu memecahkan masalah secara cepat dan tepat. Siswa mampu berpikir cepat dalam mencari akar permasalahan dari gagasan/ide yang dibahas pada suatu materi. Kemudian siswa mengidentifikasi pokok maslah yang memiliki kesamaan jenis dan fungsi. Setelah pokk masalah teridentifikasi dengan baik, kemudian adalah mengkonstruksi jawabanjawaban atas permsalahan yang dikaji. Langkah berikutnya adalah siswa mengevaluasi argumen atas jawaban-jawaban yang dikemukakan dengan cara member kesempatan kepada guru atau siswa lain dalam merespon atas argumen atau jawaban yang ditawarkan. Dengan adanya masukan atau sara maka argumen akan semakin kuat dalam member solusi atas permasalahan yang ada. Dari pihak siswa yang memberi saran atau masukan juga dapat dijadikan suatu perilaku untuk . mendeteksi dan mengkoreksi kesalahan umum dalam pemberian alasan.

Dari berbagai perilaku berpikir kritis siswa MTs Al-Amin pekalongan dapat diketahui bahwa berpikir kritis merupakan cara berpikir yang sistematis, logis, dan mendalam. Dalam pembelajaran siswa diharapkan mampu berpikir radikal dalam artian bebas, keras, 
untuk melakukan kegiatan berpikir yang mendalam dan luas terhadap suatu masalah yang ada pada materi pelajaran dengan cara mengkonseptualisasi, menganalisis dan evaluasi. Tahap-tahap berpikir kritis dalam proses pembelajaran dapat digambarkan dengan alur sebagai berikut:

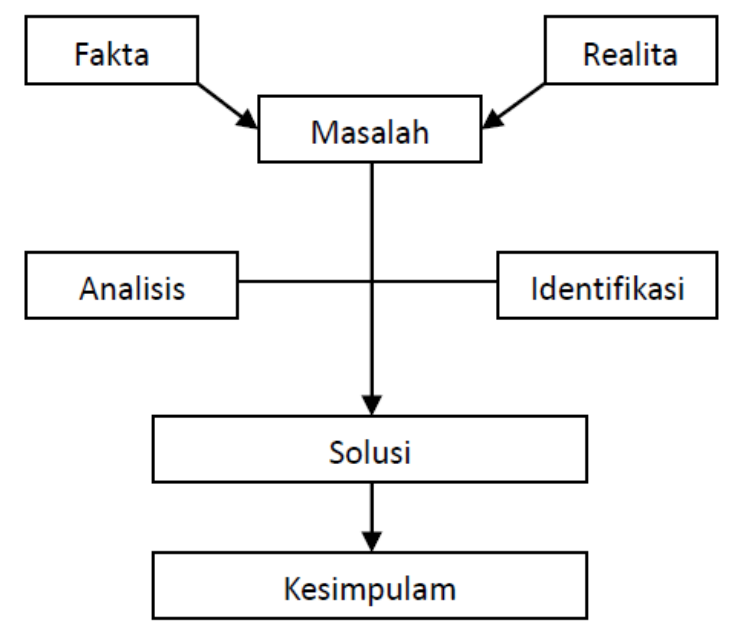

Gambar 2. Tahap berpikir kritis

\section{Keaktifan Belajar}

Menuruthisyamzaenibahwapembelajaran aktif adalah pembelajaran yang didominasi oleh siswa, dengan kata lain student center. Keaktifan siswa di kelas menjadi suatu keharusan, sedangkan guru hnaya bertindak sebagai fasilitator saja. Dominasi siswa terlihat dari cara aktifitas di kelas dalam menemukan ide pokok suatu materi pelajaran, mencari akar suatu permasalahan sekaligus mencari solusi atas permasalahan tersebut. Hal itu dapat berlaku tidak hanya ketika siswa di kelas saja, namun pada kehidupan sehari-hari di lingkungannya pun dapat belajar secara aktif. Sehingga ilmu yang didapat dari suatu materi dapat diaplikasikan dalam keberlangsungan hidupya. (Zaeni, 2007:16).

Dikatakan aktif apabila siswa itu dapat mengutarakan ide pemikirannya atau pendapat. Yang merupakan aktivitas dalam belajarnya. Memang pada dasarnya berpendapat dari suatu pemikiran tidaklah mudah untuk diutarakan, banyak dari siswa yang sebenarnya dia memiliki ide pemikiran terhadap pendapatnya namun permasalahnnya mereke kurang percaya diri dalam mengutarakannya, verbal linguistik nya kurang. Serta mental yang dimiliki siswa rendah. Maka di dalam proses pembelajaran seorang guru juga harus mampu menumbuhkan rasa percaya diri untuk anak, menumbuhkan mental anak supaya anak itu aktif sesuai perkembangannya.

Dengan kebiasaan siswa aktif dalam belajar, maka perubahan yang terjadi tidak hanya perubahan intelektualnya, namun emosional serta pengetahuannya. Dengan intelektual yang seimbang maka kedepannya anak dapat memecahkan masalah yang tibatiba terjadi entah itu dalam proses belajar atau dalam dunia nyata.

Cara guru MTs Al-Amin Pekalongan dalam meningkatkan keaktifan belajar siswanya adalah dengan cara memperbaiki keterlibatan di kelas antara lain: menggunakan teknik mengajar yang baik, motivasi, dan penguatan. Hal ini dilakukan agar siswa minat dalam menggali ilmu pengetahuan yang ada di suatu materi pelajaran. Ketrampilan guru dalam mengelola kelas yang dipadu padankan dengan metode inkuiri dapat membuat siswa tertarik, jika sudah tertarik maka akan timbul rasa senang pada diri siswa yang pada akhirnya siswa dengan senang hati untuk berpikir yang diwujudkan dalam bentuk diskusi baik antara siswa dengan siswa maupun siswa dengan guru. Oleh sebab itu, kemampuan guru harus maksimal dalam mengaitkan antara bahan, materi, dan prosedur pembelajaran. Selain itu perpindahan antar kegiatan dalam proses pembelajaran juga dilakukan dengan cara yang cepat dan tepat, sehingga siswa tidak kaget dengan peralihan aktifitas di dalam kelas yang menyebabkan minat belajar berkurang.

Partisipasi merupakan hal yang sangat penting dikelas. Jadi seorang guru harus dapat membuat siswa berpartisipasi yang diwujudkan dalam bentuk siswa mampu bertanya, memberikan pendapat, merespon pertanyaan, mengerjakan tugas, diskusi, presntasi hasil belajar. Partisipasi siswa sekecil apapun harus diapresiasi dengan baik oleh guru. Jika siswa mulai bosan dengan aktiftas pembelajaran, guru harus segera mungkin mengethui dan mengambil sikap aktif dengan menggerakkan suasana kelas agar menjadi menyenangkan. Diantara yang dapat dilakukan guru adalah mencari perhatian siswa dengan berbagai pola pertanyaan ringan mengaitkan materi dengan kehidupan 
sehari-hari. Kegiatan-kegiatan tersebut dapat menjadikan siswa aktif dalam belajar.

\section{KESIMPULAN}

Dari uraian dan pembahasan tentang penerapan metode inkuiri dalam meningkatkan keterampilan berpikir kritis dan keaktifan belajar siswa pada mata pelajaran PAI di MTs Al-Amin Pekalongan dapat disimpulkan bahwa metode inkuiri yang diterapkan di MTs Al-Amin bertujuan untuk mengembangkan pola berpikir kritis siswa. Proses interaksi pembelajaran metode inkuiri meliputi aspek keterbukaan, belajar berpikir, dan aktif bertanya. Model berpikir kritis dan keaktifan siswa MTs Al-Amin dalam belajar dapat diketahui dengan adanya pola pikir yang terstruktur dalam menemukan masalah yang berasal dari fakta dan realita yang sesuai dengan materi yang dipaparkan guru, kemudian masalah tersebut dianalisia dengan menggunakan teori/materi yang bersumber dari buku. Setelah di analisis kemudian fase mengidentifikasi masalahmasalah yang mempunyai kesamaan, sehingga memudahkan untuk mencari solusi atas permasalahan yang sudah ditemukan, kemudian tahap akhir adalah menawarkan kesimpulan, yang sebelumnya dipaparkan sebagai argumen temuan yang sudah diberi masukan dan saran dari guru dan siswa lain. Sehingga dapat dikatakan bahwa metode inkuiri dapat meningkatkan keterampilan berpikir kritis dan keaktifan siswa dalam suatu pembelajaran.

\section{DAFTAR PUSTAKA}

Triswanti, Endah. (2004). Pengaruh metode pembelajaran inkuiri terhadap hasil belajar praktik kewirausahaan ditinjau dari tingkat kognitif siswa. Jurnal Penelitian dan penilaian Pendidikan, Vol. 2, No. 2: doi https://doi.org/10.22236/ JPPP_Vol2No2Hal175-190

Atoillah. (2012). Penerapan model inkuiri dalam pembelajaran PAI untuk meningkatkan keaktifan belajar siswa. Jurnal tarbawi, vol. 1, no. 2:1-14. Doi http://jurnal. upi.edu/file/03_Penerapan_Model_ Inkuiri_-_Ato_Illah.pdf

Bahri Djamarah, Syaiful. (2013). Strategi
Belajar Mengajar. Jakarta: Rineka Cipta. Hanafiah, Nanang Dan Cucu Suhana. (2009). Konsep Strategi Pembelajaran. Bandung: PT. Refika Aditama.

Ibnu Badar Al-Tabany, Trianto. (2014). Mendesain Model Pembelajaran Inovatif, Progresif, dan Kontekstual. Jakarta: Pranemedia Group.

Majid, Abdul Dan Dian Andayani. (2004). Pendidikan Ag ama Islam Berbasis Kompetensi. Bandung: PT Remaja Rosdakarya

Molan, Benyamin. (2012). Logika IImu Dan Seni Berpikir Kritis. Jakarta: Pt Indeks.

Muchlis Solichin, Mohammad. (2017). Penerapan Model Inkuiri Discovery Dalam Pendidikan Agama Islam, Jurnal Tadris, Vol. 12, No. 2: 215-231. Doi http://dx.doi.org/10.19105/tjpi. v12i2.1580

Mustakim, Zaenal. (2009). Strategi Dan Metode Pembelajaran. Yogyakarta: Gama Media.

Nurtanto, Muhammad. 2016. Mengembangkan kompetensi profesionalisme Guru Dalam menyiapkan Pembelajaran Yang bermutu. Prosiding Seminar Nasional Inovasi pendidikan. Universitas Negeri Surakarta.

Poespoprodjo. (1985). Logika Ilmu Menalar. Bandung: Remadja Karya.

Sanjaya, Wina. (2011). Perencanaan Dan Desain Sistem Pembelajaran. Jakarta: Kencana.

Sanjaya, Wina. (2013). Strategi Pembelajaran Berorientasi Standar Proses Pendidikan. Jakarta: Kencana.

Sudjana, nana. (2011). Dasar-dasar proses belajar mengajar. Bandung: sinar baru algesindo.

Sugiono. (2010). Metode Penelitan Kuantatif Kualitatif dan R\&D . Bandung: Alfabeta.

Syafei, Isop. (2015). Pengembangan Model Pembelajaran Untuk Meningkatkan Kemampuan Berpikir Kritis Siswa, Jurnal Ilmiah Psikologi, Vol. 2, No. 2, HIm. 133140. Doi https://doi.org/10.15575/psy. v2i 2.454

Undang-Undang RI No. 20. 2003. Sistem Pendidikan Nasional (Sisdiknas). Bandung: Citra Umbara.

Zaeni, Hisyam. 2007. Strategi Pembelajaran Aktif. Yogyakarta: CTSD. 